\title{
Analysis of the Quality of the Registration Services of Haji Travelers in the Office of the Ministry of Religion, Bengkulu City
}

\section{Analisis Kualitas Pelayanan Pendaftaran Jamaah Haji pada Kantor Kementerian Agama Kota Bengkulu}

\author{
Aldi Syafitra Anwari1); Sulisti Apriani2); Abdul Rahman²) \\ 1)Study Program of Management, Faculty of Economic, Universitas Dehasen Bengkulu \\ 2) Department of Management, Faculty of Economic, Universitas Dehasen Bengkulu \\ Email: ${ }^{1)}$ aldisyafitraanwari11@gmail.com; ${ }^{2)}$ sulistiafrianifatih@gmail.com; ${ }^{2)}$ \\ abdulrahman.abd0505@gmail.com;
}

\section{How to Cite :}

Anwari, A. S., Apriani, S., Rahman, A. (2021). Analysis of the Quality of the Registration Services of Haji Travelers in the Office of the Ministry of Religion, Bengkulu City. Jurnal Ekonomi Manajemen Akuntansi Dan Keuangan, 2(4). DOI: https://doi.org/10.53697/emak.v2i4

ARTICLE HISTORY

Received [12 Agust 2021]

Revised [25 Agust 2021]

Accepted [05 October 2021]

KEYWORDS

Quality, Service, Permenpan

Number 14 of 2017

This is an open access article under the $C C-B Y$-SA license

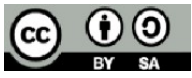

\section{ABSTRAK}

Tujuan penelitian ini adalah untuk menganalisis kualitas pelayanan pendaftaran jamaah haji pada Kantor Kementerian Agama Kota Bengkulu Permenpan Reformasi Birokrasi (RB) Nomor 14 Tahun 2017. Metode pengambilan sampel digunakan dengan simple random sampling dengan jumlah sampel 100 orang jamaah yang mendaftar haji. Metode analisis dalam penelitian ini adalah analisis kualitatif dan kuantitatif berdasarkan Permenpan RB Nomor 14 Tahun 2017. Hasil peneltian diketahui kualitas pelayanan pendaftaran jamaah haji pada Seksi PHU Kantor Kementerian Agama Kota Bengkulu dengan kriteria "Baik" yang ditunjukkan dengan nilai rata-rata dari persepsi responden 3,3011 berada pada interval 3,0644-3,532. Nilai Survei Kepuasan Masyarakat (SKM) sebesar 3,2681 berada pada interval 3,0644-3,532, begitu juga dengan nilai SKM setelah dikonversikan sebesar 81,7025 berada pada interval 76,61-88,30 dengan kriteria "Baik (B)". Diantara 9 indikator kualitas pelayanan nilai tertinggi ada pada indikator pertama, yaitu biaya/tarif dengan nilai rata-rata 4,00 berada pada interval 3,5324-4,00 dan SKM setelah dikonversikan sebesar 100,00 berada pada interval 88,31-100,000 dengan kriteria "Sangat Baik (A)". Sedangkan nilai rata-rata terendah pada indikator penanganan pengaduan saran dengan nilai rata-rata 2,94 berada pada interval 2,60-3,064 dan SKM setelah dikonversikan sebesar 73,50 berada pada interval 65,00-76,60 dengan kriteria "Kurang Baik (C)".

\section{ABSTRACT}

The purpose of this study was to analyze the quality of service for the registration of pilgrims at the Office of the Ministry of Religion of the City of Bengkulu, Permenpan RB Number 14 of 2017. The sampling method was used by simple random sampling with a sample size of 100 pilgrims who registered for the pilgrimage. The method of analysis in this research is qualitative and quantitative analysis based on Permenpan RB Number 14 of 2017. The results of the study show that the quality of the Hajj pilgrims 'registration service in the PHU Section of the Office of the Ministry of Religion of Bengkulu City with the criteria of "Good" is indicated by the average value of the respondents' perceptions of 3.3011 in the interval 3.0644-3.532. The value of the Community Satisfaction Survey (SKM) was 3.2681 in the interval 3.0644-3.532, as well as the value of SKM after 
conversion of 81.7025 in the interval 76.61-88.30 with the criteria "Good $(B)$ ". Among the 9 indicators of service quality, the highest value is in the first indicator, namely costs/tariffs with an average value of 4.00 in the 3.5324-4.00 interval and SKM after being converted at 100.00 is at the interval of 88.31-100,000 with the criteria "Very Good (A)". While the lowest average value on the indicator for handling complaints complaints with an average value of 2.94 is in the 2.60-3.064 interval and SKM after being converted is 73.50 in the interval 65.00-76.60 with the criteria "Not Good. (C) ".

\section{PENDAHULUAN}

Haji secara estimologi artinya "menyengaja" atau "menyengaja untuk melaksanakan hal-hal yang diagungkan" atau "menyengaja dengan maksud yang bermacam-macam". Ibadah haji merupakan Rukun Islam yang ke lima, dan merupakan kewajiban bagi setiap muslim yang mampu (istatha'ahi) untuk menunaikannya. Kenikmatan di dalam mengerjakannya sangat terasa sekali bagi setiap muslim yang menunaikannya. Dari situlah, semangat kaum muslimin untuk menunaikan ibadah haji terus meningkat tiap tahunnya (Umi, 2013:5).

Dalam konteks Indonesia yang mayoritas penduduknya menganut agama Islam, dari tahun ketahun terlihat antusias masyarakat untuk menunaikan rukun Islam yang ke lima semakin besar. Ini dapat dipahami mengingat haji bukan saja ibadah yang mengandung kebisaan secara sosio religius, namun juga menjadi tradisi yang sudah semakin lama berakar di kalangan masyarakat muslim Indonesia terhadap ibadah haji. Pemerintah Arab saudi memberikan kouta ibadah haji paling besar terhadap Indonesia. Oleh karena itu, pelayanan harus dilakukan secara lebih baik dan profesional. Pelayanan merupakan suatu proses yang diterapkan oleh individu atau kelompok dalam upaya-upaya kordinasi untuk mencapai suatu tujuan tertentu dipandang sebagai salah satu faktor yang sangat penting dalam menangani masalah-masalah penyelenggaraan program pelayanan. Pelayanan adalah pemberian hak dasar kepada warga negara atau masayarakat sesuai dengan kebutuhan dan kepentingannya yang diatur oleh peraturan perundang-undangan (Hayat, 2017:22).

Sebagai penyelenggara negara, salah satu fungsi yang dijalankan Aparatur Pemerintah adalah melayani masyarakat. Selama ini kualitas pelayanan publik masih dalam kondisi yang sangat memperihatinkan, ini dapat dibuktikan dengan begitu banyaknya pengaduan masyarakat terhadap kualitas pelayanan pemerintah kepada masyarakat. Pelayanan prima adalah pelayanan yang sangat baik dan melampaui harapan pelanggan, pelayanan prima harus ditetapkan, bukan hanya pada perusahaan yang menghasilkan laba melainkan instansi pemerintah pun demikian. Jadi pelayanan prima adalah kegiatan merencananakan, mengorganisasikan, mengerakkan, serta mengendalikan proses pelayannan standar yang sangat baik untuk memuaskan pelanggan agar tujuan perusahaan tercapai (Rahmayanty, 2010:7).

Dalam mewujudkan pelayanan prima tidaklah semudah membalikan telapak tangan. Banyak faktor yang perlu dipertimbangkan secara cermat, karena upaya penyempurnaan kualitas layanan berdampak signifikan terhadap budaya organisasi secara keseluruhan diantara berbagai faktor yang perlu mendapat perhatian utama adalah mengidentifikasi determinan utama kualitas jasa, mengelola ekspektasi pelanggan, mengelola bukti kualitas layanan, mendidik konsumen tentang layanan, menumbuhkan kembangkan budaya kualitas, menciptakan automating quality, menindak lanjuti layanan dan mengembangkan sistem informasi kualitas layanan (Tjiptono, 2010:99).

Pelayanan publik merupakan suatu usaha yang dilakukan kelompok atau seseorang birokrasi untuk memberikan bantuan kepada masyarakat dalam rangka mencapai suatu tujuan tertentu. Salah satu dari pelaksanaan pelayanan publik pada Kementerian Agama adalah pelayanan jamah haji. Namun pada kenyataanya penyelenggaraan pelayanan publik yang dilakukan oleh pemerintah masih dihadapkan pada pelayanan yang belum efektif dan efisien serta kualitas sumber 
daya manusia yang belum memadai. Hal ini terlihat dari masih banyaknya pengaduan dari masyarakat baik secara langsung maupun tidak langsung, seperti melalui media massa yang menuntut peningkatan kualitas pelayanan publik.

Dalam upaya meningkatkan kualitas pelayanan, Kementerian Pendayagunaan Aparatur Negara menetapkan kebijakan tentang pedoman umum penyusunan Indek Kepuasan Masyarakat (IKM) berdasarkan Keputusan Menpan Nomor 25 Tahun 2004 tentang Pedoman Umum Penyusunan Indeks Kepuasan Masyarakat Unit Pelayanan Instansi Pemerintah, yang selanjutnya disempurnakan dengan Peraturan Menteri Pendayagunaan Aparatur Negara dan Reformasi Birokrasi Nomor 14 Tahun 2017 tentang Survei Kepuasan Masyarakat (SKM). Pedoman umum ini, selain dimaksud sebagai acuan untuk mengetahui tingkat kinerja masing-masing unit pelayanan instansi pemerintah, juga diharapkan dapat memberikan kesempatan untuk menilai secara obyektif dan periodik terhadap perkembangan kinerja unit pelayanan publik.

Sedangkan indikator pelayanan untuk mengukur SKM yang mengacu pada ketentuan dalam Peraturan Menteri Pendayagunaan Aparatur Negara dan Reformasi Birokrasi Nomor 14 Tahun 2017 tentang Pedoman Penyusunan Survei Kepuasan Masyarakat. Pedoman ini untuk mengetahui penyelenggaraan pelayanan publik. Selain itu, peraturan ini dimaksudkan untuk memberikan arahan dan pedoman yang jelas dan tegas bagi penyelenggara pelayanan publik. SKM dimaksud sebagai acuan bagi unit pelayanan instansi pemerintah dalam menyusun SKM, dengan tujuan untuk mengetahui tingkat kinerja unit pelayanan secara secara berkala sebagai bahan untuk menetapkan kebijakan dalam rangka meningkatkan kualitas pelayanan publik selanjutnya.

\section{LANDASAN TEORI}

\section{Manajemen Pelayanan}

Untuk memenuhi kebutuhan hidupnya manusia berusaha, baik aktivitas sendiri, maupun secara tidak langsung melalui aktivitas orang lain. Aktivitas adalah suatu proses penggunaan akal, pikiran, panca indra dan anggota badan dengan atau tanpa alat bantu yang dilakukan oleh seseorang untuk mendapatkan sesuatu yang diinginkan baik dalam bentuk barang maupun jasa. Proses pemenuhan kebutuhan melalui aktivitas orang lain yang langsung inilah yang dinamakan pelayanan. Arti proses terbatas dalam kegiatan manajemen dalam rangka mencapai tujuan organisasi. Meskipun demikian dalam arti luas proses menyangkut segala usaha yang dilakukan oleh seseorang dalam rangka mencapai tujuan (Moenir, 2012:16).

\section{Pelayanan Publik}

Istilah lain dari pelayanan publik adalah pengabdian dan pengayoman. Dari seorang administrator diharapkan akan tercermin sifat-sifat memberikan pelayanan publik, pengabdian kepada kepentingan umum dan memberikan pengayoman kepada masyarakat lemah dan kecil. Administrator lebih menekankan pada mendahulukan kepentingan masyarakat/umum dan memberikan service kepada masyarakat ketimbang kepentingan sendiri (Thoha dalam Hardiansyah, 2011:11).

Istilah publik berasal dari bahasa inggris public yang berarti umum, masyarakat, dan negara. Kata publik sebenarnya sudah diterima menjadi Bahasa Indonesia Baku menjadi publik yang berarti umum, orang banyak, ramai. Padanan kata yang tepat digunakan adalah praja yang sebenarnya bermakna rakyat sehingga lahir istilah pamong praja yang berarti pemerintah yang melayani kepentingan seluruh rakyat.

\section{Jenis Pelayanan Publik}

Munculnya pelayanan umum atau publik dikarenakan adanya kepentingan, dan kepentingan tersebut bermacam-macam bentuknya sehingga pelayanan publik yang dilakukan ada beberapa macam. Menurut Hardiyansyah (2011:23) jenis pelayanan umum atau publik yang diberikan pemerintah terbagi dalam tiga kelompok, yaitu: Pelayanan administratif, adalah pelayanan berupa 
penyediaan berbagai bentuk dokumen yang diperlukan oleh publik, misalnya: pembuatan Kartu Tanda Penduduk (KTP), Sertifikat Tanah, Akta Kelahiran, Akta Kematian, Buku Kepemilikan Kendaraan Bermotor (BPKB), Surat Tanda Nomor Kendaraan (STNK), Izin Mendirikan Bangunan (IMB), Paspor, dan sebagainya. Pelayanan barang pelayanan barang, adalah pelayanan yang menghasilkan berbagai bentuk/jenis barang yang menjadi kebutuhan publik, misalnya: jaringan telepon, penyediaan tenaga listrik, penyediaan air bersih. Pelayanan jasa adalah pelayanan yang menghasilkan berbagai bentuk jasa yang dibutuhkan publik, misalnya: Pendidikan tinggi dan menengah, pemeliharaan kesehatan, penyelenggaraan transportasi, jasa pos, sanitasi lingkungan, persampahan, penggulangan bencana, pelayanan sosial.

\section{Survei Kepuasan Masyarakat}

Salah satu upaya untuk meningkatkan kualitas pelayanan publik, sebagaimana diamanatkan dalam Undang-Undang Republik Indonesia Nomor 25 Tahun 2000 tentang Program Pembangunan Nasional (Propenas), perlu disusun indek kepuasan masyarakat sebagai tolok ukur untuk menilai tingkat kualitas pelayanan. Disamping itu data indeks kepuasan masyarakat akan dapat menjadi bahan penilaian terhadap unsur pelayanan yang masih perlu perbaikan dan menjadi pendorong setiap unit penyelenggara pelayanan untuk meningkatkan kualitas pelayanannya.

Kebijakan pemerintah untuk mengembangkan Indek Kepuasan Masyarakat (IKM) dalam kaitannya dengan penyelenggaraan pelayanan diatur dalam Keputusan Menteri Pendayagunaan Aparatur Negara Nomor 25 Tahun 2004 tentang Pedoman Umum Penyusunan Indeks Kepuasan Masyarakat Unit Pelayanan Instansi Pemerintah yang selanjutnya disempurnakan dengan Peraturan Menteri Pendayagunaan Aparatur Negara dan Reformasi Birokrasi Nomor 14 Tahun 2017 tentang Survei Kepuasan Masyarakat (SKM). Pedoman penyusunan SKM dimaksudkan sebagai acuan bagi unit pelayanan instansi pemerintah untuk mengetahui tingkat kinerja unit pelayanan secara berkala sebagai bahan dan menetapkan kebijakan dalam rangka peningkatan kualitas pelayanan publik selanjutnya. Bagi masyarakat, SKM dapat digunakan sebagai gambaran tentang kinerja pelayanan unit yang bersangkutan.

\section{METODE PENELITIAN}

\section{Metode Analisis}

Analisis data yang digunakan dalam melakukan penelitian ini adalah:

a. Analisis kualitatif menurut Sugiyono (2011:7), adalah metode ilmiah kerena memenuhi kaedahkaedah ilmiah yaitu konkrit, objektif, terukur, rasionel dan sistematis. Analisis ini juga digunakan untuk mendeskripsikan kegiatan instansi pemerintah dalam memberikan pelayanan kepada masyarakat.

b. Analisis kuantitatif menurut Sugiyono (2011:7), adalah metode penelitian berupa angka-angka. Hasil angaka-angka tersebut diperoleh dari perhitungan untuk mendapatkan survei kepuasan masyarakat dengan rumus berdasarkan Peraturan Menteri Pendayagunaan Aparatur Negara Reformasi dan Birokrasi Nomor 14 Tahun 2017, sebagai berikut:

1. Nilai rata-rata tertimbang masing-masing pelayanan dengan 9 indikator yang dikaji, setiap unsur pelayanan memiliki penimbangan yang sama dengan rumus:

Skor KM $=\frac{\text { Total dari Nilai Persepsi Per Unsur }}{\text { Total Unsur Terisi }} \times$ Nilai Penimbang

Jumlah bobot yang ditetapkan untuk setiap pertanyaan adalah 1 dan jumlah unsur adalah jumlah pertanyaan atau indikator yang diajukan dalam hal ini 9 indikator atau 9 pertanyaan. 
2. Survei Kepuasan Masyarakat, adalah hasil dari penilaian masyarakat tentang kualitas pelayanan pendaftaran haji yang diberikan oleh Aparatur Sipil Negara (ASN) pada Seksi Penyelenggara Haji Umroh Kantor Kementerian Agama Kota Bengkulu dengan rumus: Total dari Nilai Persepsi Per Unsur

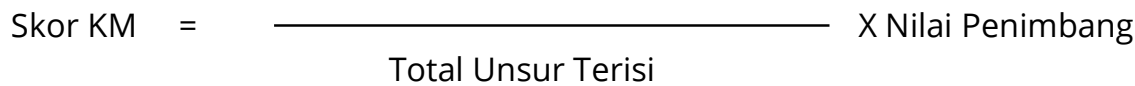

3. Nilai KM setelah dikonversikan, adalah interpretasi nilai KM yaitu antara 25-100 maka hasil penilaian dikonversikan dengan nilai dasar 25, dengan rumus:

Nilai SKM setelah dikonversikan $=$ KM Unit Pelayanan $X$ Nilai Dasar $=$ KM Unit Pelayanan $\times 25$

4. Kriteria kualitas pelayanan, untuk melihat apakah kualitas pelayanan tidak baik, kurang baik, baik dan sangat baik akan disesuaikan dengan kriteria seperti pada tabel 3.

Tabel 1. Nilai Persepsi, Nilai Interval SKM, Nilai Interval Konversi SKM, Mutu Pelayanan, dan Kinerja Unit Pelayanan

\begin{tabular}{|c|c|c|c|c|} 
Nilai Persepsi & $\begin{array}{c}\text { Nilai Interval } \\
\text { (NI) }\end{array}$ & $\begin{array}{c}\text { Nilai Interval Konversi } \\
\text { (NIK) }\end{array}$ & $\begin{array}{c}\text { Mutu } \\
\text { Pelayanan }\end{array}$ & $\begin{array}{c}\text { Kinerja Unit } \\
\text { Pelayanan }\end{array}$ \\
\hline 1 & $1,00-2,5996$ & $25,00-64,99$ & D & Tidak Baik \\
\hline 2 & $2,60-3,064$ & $65,00-76,60$ & C & Kurang Baik \\
\hline 3 & $3,0644-3,532$ & $76,61-88,30$ & B & Baik \\
\hline 4 & $3,5324-4,00$ & $88,31-100,00$ & A & Sangat Baik \\
\hline
\end{tabular}

Sumber: Permenpan RB Nomor 14 Tahun 2017

$$
Y=a+b X
$$

Keterangan:

a : Konstanta

$\mathrm{b}:$ Koefisien Korelasi

Y : Nilai Perkiraan (Proyeksi)

$X$ : Periode Waktu

\section{HASIL DAN PEMBAHASAN}

\section{Hasil dan Pembahasan}

Berdasarkan hasil perhitungan Survei Kepuasan Masyarakat (SKM) dari 100 orang responden yang merupakan masyarakat yang pernah mendapat pelayanan pendaftaran jamaah haji pada Seksi PHU Kantor Kementerian Agama Kota Bengkulu yang menjadi sampel penelitian, dari setiap unsur pertanyaan atau indikator penelitian diperoleh nilai rata-rata setiap unsur pelayanan, seperti pada tabel 9.

Tabel 2. Rata-Rata Unsur Dari Masing-Masing Indikator Penelitian

\begin{tabular}{|c|c|c|c|c|c|c|c|c|c|c|}
\hline \multirow{3}{*}{ No } & \multirow{3}{*}{$\begin{array}{l}\text { Unsur Pelayanan } \\
\text { (Indikator Penelitian }\end{array}$} & \multicolumn{8}{|c|}{ Tanggapan Responden } & \multirow{3}{*}{$\begin{array}{c}\text { Rata-Rata } \\
\text { Unsur } \\
\text { Pelayanan }\end{array}$} \\
\hline & & \multicolumn{2}{|c|}{ TB } & \multicolumn{2}{|c|}{ KB } & \multicolumn{2}{|c|}{ B } & \multicolumn{2}{|c|}{ SB } & \\
\hline & & Jlm & $\%$ & $\mathrm{Jlm}$ & $\%$ & $\mathrm{JIm}$ & $\%$ & $\mathrm{JIm}$ & $\%$ & \\
\hline 1 & Persyaratan & - & - & - & - & 37 & 37,00 & 63 & 63,00 & 3,63 \\
\hline 2 & $\begin{array}{l}\text { Sistem mekanisme dan } \\
\text { prosedur }\end{array}$ & - & - & - & - & 70 & 70,00 & 30 & 30,00 & 3,30 \\
\hline 3 & Waktu penyelesaian & - & - & - & - & 87 & 87,00 & 13 & 13,00 & 3,13 \\
\hline 4 & Biaya/tarif & - & - & - & - & - & - & 100 & 100,00 & 4,00 \\
\hline 5 & spesifikasi & - & - & - & - & 88 & 88,00 & 12 & 12,00 & 3,12 \\
\hline
\end{tabular}


p-ISSN 2798-0499 e-ISSN 2798-0502

\begin{tabular}{|r|l|c|c|c|c|c|c|c|c|c|}
\hline & jenis pelayanan & & & & & & & & & \\
\hline 6 & $\begin{array}{l}\text { Kompetensi } \\
\text { pelaksana }\end{array}$ & - & - & - & - & 83 & 83,00 & 17 & 17,00 & 3,17 \\
\hline 7 & perilaku pelaksana & - & - & - & - & 78 & 78,00 & 22 & 22,00 & 3,22 \\
\hline 8 & $\begin{array}{l}\text { Penanganan } \\
\text { pengaduan saran }\end{array}$ & - & - & 10 & 10,00 & 86 & 86,00 & 4 & 4,00 & 2,94 \\
\hline 9 & $\begin{array}{l}\text { Masukan sarana dan } \\
\text { prasarana }\end{array}$ & - & - & - & - & 80 & 80,00 & 20 & 20,00 & 3,20 \\
\hline Jumlah \\
\hline \multicolumn{10}{|l|}{ Rata-Rata } \\
\hline
\end{tabular}

Sumber: Data Diolah 2020

Keterangan:

$\begin{array}{ll}1,00-2,5996 & =\text { Tidak Baik } \\ 2,60-3,064 & =\text { Kurang Baik } \\ 3,0644-3,532 & =\text { Baik } \\ 3,5324-4,00 & =\text { Sangat Baik }\end{array}$

Dari tabel 9 di atas diketahui secara rata-rata keseluruhan bahwa kualitas pelayanan pendaftaran haji yang diberikan oleh Seksi PHU Kantor Kementrian Agama Kota Bengkulu dengan nilai rata-rata dari persepsi masyarakat sebesar 3,3011 berada pada interval 3,0644-3,532 dengan kriteria "Baik (B)".

Untuk lebih jelas tentang kualitas pelayanan pendaftaran jamaah haji pada Seksi PHU Kantor Kementerian Agama Kota Bengkulu secara keseluruhan akan dilakukan analisis dengan menggunakan Survei Kepuasan Masyarakat (SKM), sebagai berikut:

a. Nilai rata-rata tertimbang masing-masing pelayanan dengan 9 indikator yang dikaji atau diteliti, setiap unsur memiliki pertimbangan yang sama.

Jumlah Bobot

Bobot Nilai Rata-Rata Tertimbang=

Jumlah Unsur

$$
\begin{aligned}
& =\frac{1}{9} \\
& =0,11
\end{aligned}
$$

b. Survei Kepuasan Masyarakat yang merupakan hasil penilaian masyarakat tentang kualitas pelayanan jamaah haji pada Seksi PHU Kantor Kementerian Agama Kota Bengkulu.

$\begin{aligned} \text { SKM } & =\frac{\text { Total dari Nilai Persepsi Per Unsur }}{\text { Total Unsur Terisi }} \times \text { Nilai Penimbang } \\ & =\frac{2.971}{100} \times 0,11 \\ & =29,71 \times 0,11\end{aligned}$

376 | Aldi Syafitra Anwari, Sulisti Apriani, Abdul Rahman; The Effect of Remuneration and... 
c. Nilai SKM setelah dikonversikan dengan nilai dasar ditetapkan 25. Nilai SKM setelah dikonversikan $=$ SKM Unit Pelayanan $\times 25$

$$
\begin{aligned}
& =3,2681 \times 25 \\
& =81,7025
\end{aligned}
$$

d. Kriteria kualitas pelayanan berdasarkan tabel 3 berada pada interval 76,61-88,30, artinya kualitas pelayanan pendaftaran jamaah haji pada Seksi PHU Kantor Kementerian Agama Kota Bengkulu dengan mutu pelayanan "Baik (B)".

Pendaftaran jamaah haji ini adalah proses pencatatan nama, alamat, dan lain-lain untuk mendaftarkan haji melalui siskohat oleh jamaah haji pada Seksi PHU Kantor Kementrian Agama Kota Bengkulu. Jamaah yang mendaftar dengan cara datang langsung ke Kantor Kementrian Agama Kota Bengkulu melalui ruang Pelayanan Terpadu Satu Pintu (PTSP) akan dilayani oleh pegawai yang bertugas sebagai penerima pendaftaran yang kemudian dilanjutkan di ruang Seksi PHU. Pegawai akan melayani jamaah dengan suara yang sopan. Jamaah harus mengisi formulir pendaftaran dan melengkapi semua persyaratan-persyaratan. Pendaftaran jamaah haji di Kantor Kementrian Agama Kota Bengkulu calon jamaah haji diikutsertakan untuk mendaftar secara langsung di ruang Siskohat, dengan memasukan (input) data informasi calon jamaah haji yang bersangkutan, baik berupa nama, tempat tanggal lahir, alamat, nomor KTP, dan data lainnya yang kemudian dimasukan ke dalam database Siskohat.

Hasil penelitian menunjukkan bahwa unsur sistem mekanisme dan prosedur diperoleh nilai rata-rata 3,30 berada pada interval 3,0644-3,532 dengan kriteria baik artinya secara umum responden menilai bahwa sistem mekanisme dan prosedur pendaftaran jamaah haji pada Seksi PHU Kantor Kementerian Agama Kota Bengkulu sudah baik. Nilai interval SKM sebesar 82,50 (3,30 X 25) berada pada interval 76,61-88,30 dengan kriteria "Baik (B)" dengan demikian dapat diketahui bahwa kualitas pelayanan pendaftaran jamaah haji dari unsur sistem mekanisme dan prosedur pelayanan yang dirasakan sesuai dengan harapan masyarakat.

Dari hasil penelitian di atas menunjukkan bahwa kualitas pelayanan pendaftaran haji pada Seksi PHU Kantor Kementerian Agama Kota Bengkulu sudah baik. Dari 9 indikator penelitian dalam mengukur kualitas pelayanan indikator biaya/tarif mendapat penilaian paling tinggi dengan nilai rata-rata 4,00 dan nilai dan nilai interval SKM 100 dengan kriteria "Sangat Baik (A)".

\section{KESIMPULAN DAN SARAN}

\section{Kesimpulan}

1. Kualitas pelayanan pendaftaran jamaah haji pada Seksi PHU Kantor Kementerian Agama Kota Bengkulu dengan kriteria "Baik" yang ditunjukkan dengan nilai rata-rata dari persepsi responden 3,3011 berada pada interval 3,0644-3,532.

2. Nilai Survei Kepuasan Masyarakat (SKM) sebesar 3,2681 berada pada interval 3,0644-3,532, begitu juga dengan nilai SKM setelah dikonversikan sebesar 81,7025 berada pada interval 76,61-88,30 dengan kriteria "Baik (B)".

3. Diantara 9 indikator kualitas pelayanan nilai tertinggi ada pada indikator pertama, yaitu biaya/tarif dengan nilai rata-rata 4,00 berada pada interval 3,5324-4,00 dan SKM setelah dikonversikan sebesar 100,00 berada pada interval 88,31-100,000 dengan kriteria "Sangat Baik $(A)^{\prime \prime}$.

4. Dari 9 indikator pelayanan, nilai rata-rata terendah pada indikator penanganan pengaduan saran dengan nilai rata-rata 2,94 berada pada interval 2,60-3,064 dan SKM setelah dikonversikan sebesar 73,50 berada pada interval 65,00-76,60 dengan kriteria "Kurang Baik $(C)$. 
p-ISSN 2798-0499 e-ISSN 2798-0502

Saran

1. Nilai terendah kualitas pelayanan pendaftaran haji pada indikator penanganan pengaduan saran, utuk itu disarankan kepada Seksi PHU Kantor Kementerian Agama Kota Bengkulu untuk menyediakan kotak saran dan lebih baik lagi ada blok lewat website.

2. Peningkatan kenyamanan pada ruang Siskohat, sehingga jamaah yang akan diinput benarbenar merasa nyaman.

\section{DAFTAR PUSTAKA}

Adisasmita, Rahardjo. 2011. Pengelolaan Pendapatan dan Anggaran Daerah. Graha Ilmu. Jakarta. Ahmad, Batinggi. 2013. Manajerial Pelayanan Umum. Universitas Terbuka. Jakarta Boediono. 2012. Manajemen Publik. Remaja Rosdakarya. Bandung. Dessler, Gary. 2010.Manajemen Sumber Daya Manusia. Indeks. Jakarta. Gaspersz. 2013. Sistem Pemasaran. UIL. Yogyakarta. Hardiansyah. 2011. Kualitas Pelayanan Publik. Gava Media. Yogyakarta. Handoko, T. Hani. 2012. Dasar-Dasar Manajemen produksi. BPFE. Yogyakarta.

Hasibuan, Malayu. S.P. 2013. Manajemen Dasar, Pengertian dan Masalah. PT Gunung Agung. Jakarta.

Hayat. 2017. Manajemen Pelayanan Publik. PT. RajaGrafindo Persada. Jakarta.

Kementrian Agama RI. 2010. Intisari Langkah-Langkah Pembenahan Haji. Direktorat Jenderal Penyelenggara Haji dan Umroh. Jakarta.

Keputusan Menteri Pendayagunaan Aparatur Negara Nomor 25 Tahun 2004 Tentang Pedoman Umum Penyusunan Indeks Kepuasan Masyarakat Unit Pelayanan Instansi Pemerintah.

Mukarom, Zaenal. 2015. Manajemen Pelayanan Publik. Pustaka Setia. Bandung.

Moenir. H.A.S. 2012. Manajemen Pelayanan Umum di Indonesia. Bumi Aksara. Jakarta.

Nurhasyimad. 2010. http://www.damandiri.or.id /file/ nurhasyimadunairbab2. pdf.(diakses tanggal 19 September 2020 jam 11.30).

Parson, Wayne. 2011. Public Policy: Pengantar Teori dan Praktik Analisis Kebijakan.. Prenada Media. Jakarta

Peraturan Menteri Pendayagunaan Aparatur Negara dan Reformasi Birokrasi Nomor 14 Tahun 2017 tentang Pedoman Penyusunan Survei Kepuasan Masyarakat.

Pratikno. 2012, Mengelola Dinamika Politik dan Sumberdaya Daerah. DEPDAGRI. Yogyakarta.

Rahmayanty, Nina. 2010. Manajemen Pelayanan Prima. Graha Ilmu. Yogyakarta.

Ratminto dan Atik Septi Winarsih. 2014. Manajemen Pelayanan. Pustaka Pelajar. Yogyakarta.

Saefullah. 2010. Konsep dan Metode Pelayanan Umum yang Baik. Jurnal. Fisip Unpad.

Sedarmayanti. 2011. Manajemen Sumber Daya Manusia berbasis Modern. Jaya Putra. Yogyakarta.

Sinambela, Lijan Poltak. 2010. Reformasi Pelayanan Publik Teori, Kebijakan dan Implementasi. Bumi Aksara. Jakarta.

Sugiyono. 2011. Metode Penelitian Bisnis. Bandung. Alfabeta.

Syafiie, Inu Kencana. 2011. Ilmu Administrasi Publik. PT. Rineka Cipta. Jakarta.

Tjiptono, Fandy. 2010. Service Manajemen Mewujudkan Layanan Prima, CV. Andi Offset. Yogyakarta. Umi, Aqilia. 2013. Panduan Praktis Haji \& Umroh. Al-Maghfiroh. Jakarta.

Verawati. 2019. Analisis Kualitas Pelayanan Pada Dinas Kependudukan dan Pencatatan Sipil Kabupaten Kepahiang. Fakultas Ekonomi Universitas Dehasen Bengkulu.

Wijaya, Toni. 2011. Manajemen Kualitas Jasa. PT Indeks. Jakarta.

Wyckof. 2013. Managing Services Companies: Strategies for Succes. England. Addison Wesley. Publishing. Gramedia. Jakarta.

Yamit, Zuliyan. 2015. Manajemen Kualitas Produk dan Jasa. Ekonesia. Jakarta. 
Ziarawati, Egustina. 2016. Analisis Kualitas Pelayanan Pada Unit Pelaksana Teknis Dinas Pengelola Air Minum (UPTD PAM) Kabupaten Kaur. Fakultas Ekonomi Universitas Dehasen Bengkulu. 